\title{
Erratum to: Determining recreational, scenic, and historical- cultural potentials of landscape features along a segment of the ancient Silk Road using factor analyzing
}

\author{
Oguz Kurdoglu • Banu Cicek Kurdoglu
}

Published online: 18 August 2013

(C) Springer Science+Business Media Dordrecht 2013

Erratum to: Environ Monit Assess, (2010) 170, pp. 99-116

DOI 10.1007/s10661-009-1219-8

The original version of this article unfortunately contained a mistake. Acknowledgment section was missing in the original version of this article. The acknowledgment is given below.

Acknowledgments

We would like to thank TUBITAK (The Scientific and Technological Research Council of Turkey) and Scientific Research Project Unit of Karadeniz Technical University and Dr. Mustafa Var who is the project coordinator for supporting us.

The online version of the original article can be found at http://dx. doi.org/10.1007/s10661-009-1219-8.

O. Kurdoglu $(\bowtie)$

Faculty of Forestry, Artvin Coruh University, 08000 Artvin, Turkey

e-mail: kurdoguz@hotmail.com

B. C. Kurdoglu

Faculty of Forestry, Department of Landscape

Architecture, Karadeniz Technical University,

61080 Trabzon, Turkey

e-mail: banucisali@hotmail.com 